\title{
Development and quality mapping of iron fortified jamun (Syzygium cumini) leather
}

\author{
Nosheen Naz ${ }^{1, *}$, Moazzam Rafiq Khan ${ }^{1}$, Muhammad Asim Shabbir ${ }^{1}$ and M. Naeem Faisal ${ }^{2}$ \\ ${ }^{1}$ National Institute of Food Science and Technology, Faculty of Food, Nutrition and Home Sciences, University of \\ Agriculture Faisalabad, 38000, Pakistan; ${ }^{2}$ Institute of Pharmacy, Physiology, and Pharmacology, University of Agriculture, \\ Faisalabad, 38000, Pakistan \\ *Corresponding author's e-mail: noshinaz93@gmail.com
}

\begin{abstract}
Focused on the iron-fortification of underutilized food sources of Pakistan, jamun was selected as a vehicle fruit for iron supplementation in the form of jamun leather. Iron-fortified jamun leather was prepared from two varieties available in Pakistan i.e., Desi jamun (V1) and Ra jamun (V2) using ferrous sulfate as a fortificant. The treatments prepared were V1T1, V1T2, V2T1 and V2T2 having iron value of $40 \%$ (T1) and 60\% (T2) recommended daily allowance (RDA). The analyses as physiochemical, phytochemicals, mineral and sensory evaluations were conducted at 0,30th, 60th, 90th and 120th day. During the study, $\mathrm{pH}$, ascorbic acid, total phenolic contents (TPC) and (2,2-diphenyl-1-picrylhydrazyl) DPPH showed a declining trend, whereas reducing sugar, acidity and brix value increased during storage period. During the study, the highest reduction of $\mathrm{pH}$ was observed in V1T1 (3.38 \pm 0.021$)$, maximum ascorbic acid was determined in Desi jamun (V1) in a range of 6.81$6.94 \mathrm{mg} / 100 \mathrm{~g}$. Similarly, Desi jamun (V1) had more total phenolic contents i.e., $1372 \mathrm{mg}$ GAE/100g and remarkable DPPH antioxidant activity as $85 \%$ as compared to Ra jamun (V2). The sensory parameters such as color, flavor, taste and overall acceptability showed varying preferences of iron fortification among treatments. Based on analyses outcome, V1T1 and V1T2 were most appropriate treatments having the maximum chemical and organoleptic analysis score amongst all the treatments.
\end{abstract}

Keywords: Jamun, iron deficiency, fortification, jamun leather.

\section{INTRODUCTION}

Adequate nutrition plays a pivotal role in proper physical and mental health. Any imbalance may lead to abnormality in body function and growth. It is necessary to obtain the deficient nutrients from the food otherwise body undergoes nutrient deficiency i.e., malnutrition (Asad and Mushtaq, 2012). Iron deficiency anaemia (IDA) is the decrease in total iron content of the body, which may lead to compromised health. It results in poor cognitive and neurological development among children, high maternal mortality and low productivity in adults (Balarajan et al., 2011). In Pakistan, the prevalence of IDA women is about $40-60 \%$ associated with severe blood loss in chronic cases (Parks et al., 2018). The National Nutrition Survey of Pakistan (NNS, 2018) has indicated that approximately $27 \%$ of children under 5 are iron deficient whereas $19 \%$ of women of reproductive age are unable to achieve required iron level. In present scenario, diet is not only the source to reduce hunger but also to supply basic nutrients to prevent nutrition-related ailments. The development of efficient strategies for control of iron deficiency anaemia is a great challenge in various regions of the world, especially in Pakistan. Such strategies include nutrition education, supplements for vulnerable population as well as food fortification. Among all the strategies, the fortification is the best approach to provide the micronutrient to the targeted segment of community. According to the Codex Alimentarius, fortification is the addition of one or more nutrients in a diet that are mostly present in the diet in low amount to increase the nutritional status of the deficient population (Dwyer et al., 2014). The process of fortification is based on standard laws and principles to control malnutrition issues.

Fruits are undoubtedly important for the provision of nutrition to the living beings along with a high potential of value addition and commercialization. In the present world, consumers are becoming conscious about their health and the nutritional profile of the food they consumed. They are preferring to take food from natural resources rather than using chemical and synthetic foods (Viswanath et al., 2018). Post-harvest losses of fruits are becoming a serious issue, so it is necessary to transform such fruits in value-added products. Jamun is one of those fruits which are unfortunately not properly stored thus encounters major post-harvest losses.

Naz, N., M.R. Khan, M.A. Shabbir and M.N. Faisal. 2021. Development and quality mapping of iron fortified jamun (Syzygium cumini) leather. Pak. J. Agri. Sci.58:1323-1330.

[Received 28 Aug 2020; Accepted 5 Jul 2021; Published (online) 21 Sep 2021] 


\section{Naz, Khan, Shabbir \& Faisal}

Jamun is seasonal, perishable and underutilized indigenous fruits with a lot of medicinal benefits. The fruit contains a varying amount of minerals, vitamin $\mathrm{C}$, phenolic compounds, sugars and antioxidant components (Prabhakaran et al., 2011). Mainly, jamun fruit is processed to prepare vinegar, squash, jam and jellies. Jamun product is attractive to consumers due to the eye-appealing purple color contributed by anthocyanins pigments. Moreover, the jamun flavonoids act as both antioxidants and colorant (Bukya and Madane, 2018). Most fruits have a short harvest season and such fruits are sensitive to the deterioration even these are stored in the refrigerator in favorable condition. Fruit leathers are the dehydrated and concentrated fruit based flexible sheet that are consumed as a dessert or snack with rich nutritional profile (Khayum et al., 2018). Thus, fruit leather is the most effective way to preserve fruit pulp. Moreover, it is the best way to give fruit solid to children and adolescents. Fruit leathers can be stored for a longer period of time without any undesirable change in texture and the flavor (Basha et al., 2018).

The purpose of the present study was to prepare iron fortified jamun leather and use it to combat iron deficiency anemia. During the study, nutritional profiling including the iron level, total phenolic compounds, antioxidant activity using the DPPH assay were carried out. Additionally, the physicochemical and organoleptic evaluation was done.

\section{MATERIALS AND METHODS}

Procurement of raw material and sample preparation: The two varieties of Jamun (Syzygium cumini), Ra and Desi, were purchased from Ayub Agriculture Research Institute, Faisalabad keeping in view the quality traits for example size uniformity, shape and color followed by washing and grading. The seed was separated from the pulp for the analysis. The fruit pulp samples were preceded for the proximate and mineral analysis.

Nutritional profiling of Jamun varieties pulp

Proximate and mineral analysis: The proximate analysis of jamun varieties including ash, moisture, crude fat, crude fiber and crude protein were carried out according to the standard method of AOAC (2016). Minerals such as $\mathrm{K}$ and $\mathrm{Na}$ of jamun pulp were quantified by Flame Photometer whilst $\mathrm{Ca}$, Fe and $\mathrm{Zn}$ were determined using the Atomic Absorption Spectrophotometer technique (AOAC, 2016). All the tests were performed in triplicates.

Preparation of fortified jamun leather: Jamun varieties were passed through the pulper for the pulp that was further used for the preparation of jamun leather. The jamun pulp was homogenized using the lab homogenizer. During the homogenization, the other ingredients such as pectin, citric acid and sugar were added to the mixture. After homogenization, the mixture was pasteurized and followed by the addition of iron salt and mixed thoroughly to avoid any precipitation of salt. The ferrous sulphate was added in samples to yield $7.2 \mathrm{mg}$ (40\% of Recommended Daily Allowance (RDA)) and $10.7 \mathrm{mg} / 100 \mathrm{~g}$ (60\% of RDA) of jamun leather according to the treatments separately. The mixture was taken in aluminium trays and a thin layer of vegetable oil was smeared in the aluminium trays to avoid sticking of leather. The process of dehydration was done in the cabinet dryer at a temperature of $60^{\circ} \mathrm{C}$ and the air velocity was set at $3.5 \mathrm{~m} / \mathrm{sec}$ in cabinet dryer for about 7 to 8 hours. The leather was cut into desired shapes weighing $10 \mathrm{~g}$. The jamun leather was wrapped in butter paper and then stored in the polythene bags that were labelled according to the treatments prepared. Fortified jamun leather was prepared using both of the varieties separately using ferrous sulfate as a fortificant.

Physicochemical analysis: The physicochemical analysis including the $\mathrm{pH}$, total soluble solids (TSS), acidity, reducing sugars and ascorbic acid were analyzed by Kaleem et al. (2017).

Mineral analysis/Iron determination: Fe level of the fortified jamun leather was determined by using an atomic absorption spectrophotometer as mentioned by AOAC (2016).

Total Phenolic content: The total phenolic content of ironfortified jamun leather were determined by using the method of Phuong et al. (2017).

DPPH radical scavenging activity: The in vitro antioxidant activity was assessed by using DPPH assay according to the method mentioned by Ahmad et al. (2018).

Sensory evaluation: The sensory properties of iron-fortified leather including taste, flavor, color and overall acceptability were assessed by the 20 volunteers by using a 9 -point hedonic scale.

Statistical Analysis: The data obtained were subjected to statistical analysis using a two-way factorial completely randomized design (CRD) and the means were compared using LSD (least significant difference) test at $0.05 \%$ significant level using the Statistix software and following the methods explicated by Montgomery (2008).

Table 1. Treatment plan of iron-fortified jamun leather (10g).

\begin{tabular}{lcc}
\hline Treatments & Pulp \% & FeSO $4.7 H_{2}$ O $(\%$ RDA $)$ \\
\hline $\mathrm{V}_{1} \mathrm{~T}_{1}$ & 100 & 40 \\
$\mathrm{~V}_{1} \mathrm{~T}_{2}$ & 100 & 60 \\
$\mathrm{~V}_{2} \mathrm{~T}_{1}$ & 100 & 40 \\
$\mathrm{~V}_{2} \mathrm{~T}_{2}$ & 100 & 60 \\
\hline
\end{tabular}

$\mathrm{V}_{1}=$ Desi jamun pulp; $\mathrm{V}_{2}=\mathrm{Ra}$ jamun pulp; $40 \%$ and $60 \% \mathrm{RDA}-\mathrm{Fe}$ requirement of adult females ( $18 \mathrm{mg} /$ day)

\section{RESULTS AND DISCUSSION}

Compositional profiling of jamun varieties pulp: Proximate analysis plays an important role in examining the qualities of the raw material. The results of the present study for 
proximate analysis of jamun varieties pulp are mentioned in Table 2. The values of the proximate analysis including moisture, ash, protein, fiber, fat and nitrogen-free extract in desi jamun were $84.08 \pm 0.03,2.09 \pm 0.08,2.14 \pm 0.02$, $1.77 \pm 0.02,0.157 \pm 0.02$ and $9.77 \pm 0.29 \mathrm{~g} / 100 \mathrm{~g}$ whilst in $\mathrm{Ra}$ jamun $82.11 \pm 0.04, \quad 2.15 \pm 0.08,2.09 \pm 0.02, \quad 2.06 \pm 0.07$, $1.51 \pm 0.04$ and $10.07 \pm 0.32 \mathrm{~g} / 100 \mathrm{~g}$. The present results of the proximate assay are in corroboration with the findings of Suradkar et al. (2017), who evaluated crude fat, moisture, ash, crude protein, crude fiber as $0.29,81.25,0.85,1.26$ and $1.05 \%$ respectively. The current outcomes are also following the same pattern reported by Ghosh et al. (2017) as $79.25 \%$ moisture in jamun pulp whilst the remaining contents ash, fat and protein were $1.03,0.18$ and $0.65 \mathrm{~g} / 100 \mathrm{~g}$, respectively. Although minerals are not used as a source of energy, however these are required for the physiological functions of the body. Fruits are considered to be a good source of minerals. Owing to this jamun is considered to be a highly nutritive fruit containing important minerals (Saeed et al.,2018). In the present exploration, the minerals like iron $(\mathrm{Fe})$, calcium $(\mathrm{Ca})$, zinc $(\mathrm{Zn})$, sodium $(\mathrm{Na})$ and potassium $(\mathrm{K})$ in desi and $\mathrm{Ra}$ jamun pulp were documented as $2.36 \pm 0.20$, $20.04 \pm 0.81,0.31 \pm 0.02,7.73 \pm 0.17,183.4 \pm 0.51 \mathrm{mg} / 100 \mathrm{~g}$ and $2.36 \pm 0.19,24.33 \pm 0.91,0.24 \pm 0.03,3.30 \pm 0.30$ and $172.9 \pm 0.55$ $\mathrm{mg} / 100 \mathrm{~g}$ respectively (Table 2). Previously, Ali et al. (2013) recorded 8.61, 87.91, 24.30 and $3.04 \mathrm{mg}$ of sodium, potassium, calcium and iron in $100 \mathrm{~g}$ of dry jamun pulp. Moreover, Nawaz et al. (2011) observed $0.88 \mathrm{mg} / 100 \mathrm{~g}$ magnesium in jamun pulp whilst the remaining minerals including $0.88 \mathrm{mg} / 100 \mathrm{~g}$ iron, $1.5 \mathrm{mg} / 100 \mathrm{~g}$ zinc, $19.9 \mathrm{mg} / 100 \mathrm{~g}$ sodium and $196.8 \mathrm{mg} / 100$ potassium were also observed. The proximate composition and the mineral contents might deviate due to the changes in geographical conditions, agronomic practices and ripening stage.

Table 2. Compositional profiling of jamun varieties pulp Proximate analysis (\%)

\begin{tabular}{|c|c|c|}
\hline & Desi jamun & Ra jamun \\
\hline Moisture & $84.08 \pm 0.03$ & $82.11 \pm 0.04$ \\
\hline Ash & $2.09 \pm 0.08$ & $2.15 \pm 0.08$ \\
\hline Crude protein & $2.14 \pm 0.02$ & $2.09 \pm 0.02$ \\
\hline Crude fiber & $1.77 \pm 0.02$ & $1.98 \pm 0.04$ \\
\hline Crude fat & $1.57 \pm 0.03$ & $1.51 \pm 0.04$ \\
\hline \multirow{3}{*}{$\begin{array}{l}\text { Nitrogen free } \\
\text { extract (NFE) }\end{array}$} & $9.77 \pm 0.29$ & $10.07 \pm 0.32$ \\
\hline & \multicolumn{2}{|c|}{ Mineral analysis(mg/100g) } \\
\hline & Desi jamun & Ra jamun \\
\hline $\mathrm{Fe}$ & $2.36 \pm 0.20$ & $2.36 \pm 0.19$ \\
\hline $\mathrm{Ca}$ & $20.04 \pm 0.81$ & $24.33 \pm 0.91$ \\
\hline $\mathrm{Zn}$ & $0.31 \pm 0.02$ & $0.24 \pm 0.03$ \\
\hline $\mathrm{Na}$ & $7.73 \pm 0.17$ & $3.30 \pm 0.30$ \\
\hline $\mathrm{K}$ & $183.40 \pm 0.51$ & $172.90 \pm 0.55$ \\
\hline
\end{tabular}

Storage study of jamun leather: The fortified Jamun leather treatments were stored at room temperature. The leather was stored for 120 days, during this tenure the changes in the jamun leather composition were observed some of those are discussed below.

$\boldsymbol{p H}$ : The mean squares related to $\mathrm{pH}$ of the leather predicted that there was a non-significant effect on treatments whilst the storage has a significant effect on $\mathrm{pH}$ (Table 3). The maximum reduction of $6 \%$ was observed in $\mathrm{V}_{1} \mathrm{~T}_{2}$, which is from 3.46 \pm 0.11 (initial day) to 3.25 \pm 0.10 (last day). A similar trend of reduction during the storage is observed in other three treatments, such as in $\mathrm{V}_{2} \mathrm{~T}_{2} \mathrm{pH}$ calculated at day 0 was $3.42 \pm 0.11$ which decreased to $3.24 \pm 0.10$ at the end day of the study. The results of $\mathrm{pH}$ are in accordance Kaleem et al. (2017). They prepared strawberry leather using different concentrations of sucrose and honey and further analyzed various physicochemical analysis including $\mathrm{pH}$. They reported a decrease in $\mathrm{pH}$ value from 3.64 to 3.48 at the end of the study. Similarly, in another research, guava leather was and packed the in different packing material according to the researchers the $\mathrm{pH}$ of the leather was decreased during the storage study (Offia-Olua and Ekwunife, 2015). The factors responsible for fall in the values of $\mathrm{pH}$ during the storage might be the oxidation or denaturation of protein present in the product (Akhtar et al., 2014)

Acidity: The acidity of the fortified jamun leather was significantly affected during storage (Table 3 ). The maximum increase in acidity was observed in $\mathrm{V}_{2} \mathrm{~T}_{2}$ which was $0.48 \pm 0.017$ to $0.63 \pm 0.025$ followed by $\mathrm{V}_{1} \mathrm{~T}_{2}$ that increased from $0.49 \pm 0.017$ to $0.63 \pm 0.021$ during the storage of 120 days. Whereas the $\mathrm{V}_{2} \mathrm{~T}_{1}$ showed a less increase in the acidity from $0.46 \pm 0.021$ ( 0 day) to $0.59 \pm 0.015\left(120^{\text {th }}\right.$ day). The present findings are in alignment with the results of Basha et al. (2018), noticed a gradual rise in the acidity of the guava leather throughout the storage of 90 days. They prepared guava leather and predicted the acidity 0.55 on day 0 which gradually increases up to 0.563 at the $30^{\text {th }}$ day of the study. A similar trend of increase in acidity was observed by Saranya et al. (2017), they prepared papaya fruit rollups. According to their research the acidity of the leather increase during 10 weeks i.e., from 0.36 to 0.65 till the final day of their study. The rise in the acidity might be owing to the breakdown of the pectic bodies which in return increased the chances of the development of the acidic substances (Shakoor et al., 2015).

Total Soluble Solids (Brix ${ }^{\circ}$ ): The treatments and the storage time showed a non-significant effect on brix. The mean values of brix showed in Table 3 were $50.78 \pm 1.69$, 50.98 \pm 1.67 , $50.17 \pm 1.68$ and $50.72 \pm 1.66$ for $\mathrm{V}_{1} \mathrm{~T}_{1}, \mathrm{~V}_{1} \mathrm{~T}_{2}, \mathrm{~V}_{2} \mathrm{~T}_{1}$ and $\mathrm{V}_{2} \mathrm{~T}_{2}$ whilst during the storage interval the brix increase from $49.81 \pm 1.71$ to $51.48 \pm 1.65$. Depending on the conditions the brix may vary. According to Chavan and Shaik (2015) observed an increase in TSS during the storage of guava leather. In some cases, the increase in brix was linked with the conversion of insoluble polysaccharide starches into soluble 
Naz, Khan, Shabbir \& Faisal

Table 3. Effects of storage and treatment on pH, acidity, TSS, reducing sugars and ascorbic acid of jamun leather.

\begin{tabular}{|c|c|c|c|c|c|c|}
\hline \multirow[b]{2}{*}{ Parameter } & \multirow[b]{2}{*}{ Storage Days } & \multicolumn{4}{|c|}{ Treatments } & \multirow[b]{2}{*}{ Means } \\
\hline & & $\mathbf{V}_{1} \mathbf{T}_{1}$ & $\mathbf{V}_{1} T_{2}$ & $\mathrm{~V}_{2} \mathrm{~T}_{1}$ & $\mathrm{~V}_{2} \mathrm{~T}_{2}$ & \\
\hline \multirow[t]{6}{*}{$\mathrm{pH}$} & 0 & $3.47 \pm 0.11^{\mathrm{a}}$ & $3.46 \pm 0.11^{\mathrm{a}}$ & $3.45 \pm 0.11^{\mathrm{ab}}$ & $3.42 \pm 0.11^{\mathrm{abc}}$ & $3.45 \pm 0.116^{\mathrm{a}}$ \\
\hline & 30 & $3.43 \pm 0.10^{\mathrm{abc}}$ & $3.42 \pm 0.10^{\mathrm{a}-\mathrm{d}}$ & $3.41 \pm 0.10^{\mathrm{a}-\mathrm{d}}$ & $3.37 \pm 0.10^{\mathrm{a}-\mathrm{d}}$ & $3.41 \pm 0.107^{\mathrm{a}}$ \\
\hline & 60 & $3.38 \pm 0.10^{\mathrm{a}-\mathrm{d}}$ & $3.38 \pm 0.11^{\mathrm{a}-\mathrm{d}}$ & $3.36 \pm 0.11^{\mathrm{a}-\mathrm{d}}$ & $3.33 \pm 0.10^{\mathrm{a}-\mathrm{d}}$ & $3.37 \pm 0.109^{\mathrm{ab}}$ \\
\hline & 90 & $3.34 \pm 0.10^{\mathrm{a}-\mathrm{d}}$ & $3.32 \pm 0.11^{\mathrm{a}-\mathrm{d}}$ & $3.31 \pm 0.11^{\mathrm{a}-\mathrm{d}}$ & $3.29 \pm 0.11^{\mathrm{a}-\mathrm{d}}$ & $3.32 \pm 0.111^{b c}$ \\
\hline & 120 & $3.27 \pm 0.10^{\mathrm{bcd}}$ & $3.25 \pm 0.10^{\mathrm{cd}}$ & $3.26 \pm 0.10^{\mathrm{cd}}$ & $3.24 \pm 0.10^{\mathrm{d}}$ & $3.26 \pm 0.103^{c}$ \\
\hline & Means & $3.38 \pm 0.021^{\mathrm{a}}$ & $3.37 \pm 0.01^{\mathrm{a}}$ & $3.36 \pm 0.018^{\mathrm{a}}$ & $3.34 \pm 0.020^{\mathrm{a}}$ & \\
\hline \multirow[t]{6}{*}{ Acidity } & 0 & $0.47 \pm 0.01^{\mathrm{j}}$ & $0.49 \pm 0.01^{\mathrm{hij}}$ & $0.46 \pm 0.02^{\text {hij }}$ & $0.48 \pm 0.01^{\mathrm{ij}}$ & $0.48 \pm 0.019^{\mathrm{e}}$ \\
\hline & 30 & $0.52 \pm 0.02^{\mathrm{fgh}}$ & $0.51 \pm 0.02^{\text {fgh }}$ & $0.51 \pm 0.02^{\mathrm{fgh}}$ & $0.53 \pm 0.02^{\mathrm{fgh}}$ & $0.52 \pm 0.020^{\mathrm{d}}$ \\
\hline & 60 & $0.54 \pm 0.02^{\text {efg }}$ & $0.55 \pm 0.01^{\mathrm{def}}$ & $0.53 \pm 0.01^{\mathrm{def}}$ & $0.57 \pm 0.02^{\text {cde }}$ & $0.55 \pm 0.020^{c}$ \\
\hline & 90 & $0.58 \pm 0.02^{\mathrm{bcd}}$ & $0.59 \pm 0.01^{b c}$ & $0.57 \pm 0.01^{\mathrm{bcd}}$ & $0.58 \pm 0.02^{\text {bcd }}$ & $0.58 \pm 0.020^{b}$ \\
\hline & 120 & $0.6 \pm 0.02^{\mathrm{ab}}$ & $0.63 \pm 0.02^{\mathrm{a}}$ & $0.59 \pm 0.01^{\mathrm{ab}}$ & $0.63 \pm 0.02^{\mathrm{a}}$ & $0.61 \pm 0.021^{\mathrm{a}}$ \\
\hline & Means & $0.54 \pm 0.02^{\mathrm{a}}$ & $0.55 \pm 0.01^{\mathrm{a}}$ & $0.53 \pm 0.01^{\mathrm{a}}$ & $0.56 \pm 0.02^{\mathrm{a}}$ & \\
\hline \multirow[t]{6}{*}{$\operatorname{TSS}\left(\right.$ Brix $\left.^{\circ}\right)$} & 0 & $50.19 \pm 1.70^{\mathrm{a}}$ & $50.15 \pm 1.70^{\mathrm{a}}$ & $49.34 \pm 1.70^{\mathrm{a}}$ & $49.56 \pm 1.60^{\mathrm{a}}$ & $49.81 \pm 1.70^{\mathrm{a}}$ \\
\hline & 30 & $50.55 \pm 1.60^{\mathrm{a}}$ & $50.48 \pm 1.60^{\mathrm{a}}$ & $49.48 \pm 1.60^{\mathrm{a}}$ & $49.91 \pm 1.60^{\mathrm{a}}$ & $50.11 \pm 1.60^{\mathrm{ab}}$ \\
\hline & 60 & $50.92 \pm 1.60^{\mathrm{a}}$ & $50.95 \pm 1.60^{\mathrm{a}}$ & $50.90 \pm 1.60^{\mathrm{a}}$ & $51.06 \pm 1.60^{\mathrm{a}}$ & $50.96 \pm 1.60^{\mathrm{ab}}$ \\
\hline & 90 & $51.01 \pm 1.70^{\mathrm{a}}$ & $51.42 \pm 1.70^{\mathrm{a}}$ & $50.96 \pm 1.70^{\mathrm{a}}$ & $51.28 \pm 1.70^{\mathrm{a}}$ & $50.97 \pm 1.70^{\mathrm{ab}}$ \\
\hline & 120 & $51.24 \pm 1.60^{\mathrm{a}}$ & $51.89 \pm 1.60^{\mathrm{a}}$ & $50.98 \pm 1.60^{\mathrm{a}}$ & $51.81 \pm 1.60^{\mathrm{a}}$ & $51.48 \pm 1.60^{\mathrm{b}}$ \\
\hline & Means & $50.78 \pm 1.69^{\mathrm{a}}$ & $50.98 \pm 1.67^{\mathrm{a}}$ & $50.17 \pm 1.68^{a}$ & $50.72 \pm 1.66^{\mathrm{a}}$ & \\
\hline Reducing & 0 & $13.07 \pm 0.52^{\mathrm{e}-\mathrm{h}}$ & $12.90 \pm 0.45^{\mathrm{fgh}}$ & $12.48 \pm 0.41^{\mathrm{h}}$ & $12.77 \pm 0.50^{\mathrm{gh}}$ & $12.75 \pm 0.47^{\mathrm{d}}$ \\
\hline \multirow[t]{5}{*}{ sugars } & 30 & $13.57 \pm 0.48^{c-f}$ & $13.27 \pm 0.44^{\mathrm{d}-\mathrm{g}}$ & $12.84 \pm 0.48^{\mathrm{fgh}}$ & $13.09 \pm 0.46^{\mathrm{e}-\mathrm{h}}$ & $13.19 \pm 0.46^{\mathrm{c}}$ \\
\hline & 60 & $13.82 \pm 0.43^{\mathrm{b}-\mathrm{e}}$ & $13.87 \pm 0.52^{\mathrm{bcd}}$ & $13.29 \pm 0.51^{\mathrm{defg}}$ & $13.54 \pm 0.52^{\mathrm{c}-\mathrm{f}}$ & $13.63 \pm 0.50^{\mathrm{b}}$ \\
\hline & 90 & $14.14 \pm 0.50^{\mathrm{abc}}$ & $14.49 \pm 0.45^{\mathrm{ab}}$ & $14.25 \pm 0.47^{\mathrm{abc}}$ & $13.99 \pm 0.41^{\mathrm{a}-\mathrm{d}}$ & $14.28 \pm 0.46^{\mathrm{a}}$ \\
\hline & 120 & $14.52 \pm 0.45^{\mathrm{ab}}$ & $14.74 \pm 0.44^{\mathrm{a}}$ & $14.73 \pm 0.44^{\mathrm{a}}$ & $14.45 \pm 0.46^{\mathrm{ab}}$ & $14.55 \pm 0.45^{\mathrm{a}}$ \\
\hline & Means & $13.82 \pm 0.48^{\mathrm{a}}$ & $13.81 \pm 0.46^{\mathrm{a}}$ & $13.75 \pm 0.46^{\mathrm{a}}$ & $13.57 \pm 0.47^{\mathrm{a}}$ & \\
\hline Ascorbic acid & 0 & $7.15 \pm 0.59^{a}$ & $7.09 \pm 0.62^{\mathrm{a}}$ & $6.55 \pm 0.54^{\mathrm{a}-\mathrm{d}}$ & $6.49 \pm 0.65^{\mathrm{a}-\mathrm{d}}$ & $6.82 \pm 0.60^{\mathrm{a}}$ \\
\hline \multirow[t]{5}{*}{$(\mathrm{mg} / 100)$} & 30 & $7.05 \pm 0.56^{\mathrm{ab}}$ & $6.9 \pm 0.58^{\mathrm{a}-\mathrm{d}}$ & $6.48 \pm 0.50^{\mathrm{a}-\mathrm{d}}$ & $6.38 \pm 0.61^{\mathrm{a}-\mathrm{d}}$ & $6.70 \pm 0.56^{\mathrm{ab}}$ \\
\hline & 60 & $6.93 \pm 0.57^{\mathrm{abc}}$ & $6.77 \pm 0.59^{a-d}$ & $6.39 \pm 0.51^{\mathrm{a}-\mathrm{d}}$ & $6.23 \pm 0.62^{\mathrm{a}-\mathrm{d}}$ & $6.58 \pm 0.57^{\mathrm{ab}}$ \\
\hline & 90 & $6.85 \pm 0.58^{\mathrm{a}-\mathrm{d}}$ & $6.69 \pm 0.61^{\mathrm{a}-\mathrm{d}}$ & $6.25 \pm 0.52^{\mathrm{a}-\mathrm{d}}$ & $6.14 \pm 0.62^{b c d}$ & $6.48 \pm 0.58^{\mathrm{ab}}$ \\
\hline & 120 & $6.71 \pm 0.54^{\mathrm{a}-\mathrm{d}}$ & $6.61 \pm 0.56^{\mathrm{a}-\mathrm{d}}$ & $6.03 \pm 0.48^{\mathrm{cd}}$ & $5.96 \pm 0.57^{\mathrm{d}}$ & $6.33 \pm 0.54^{b}$ \\
\hline & Means & $6.94 \pm 0.57^{\mathrm{a}}$ & $6.81 \pm 0.58^{a}$ & $6.34 \pm 0.51^{\mathrm{b}}$ & $6.24 \pm 0.61^{b}$ & \\
\hline
\end{tabular}

di and mono-saccharides (Shakoor et al., 2015). According to Saranya et al. (2017), the brix of the papaya leather rollups decreases from $80.60^{\circ}$ to $78.34^{\circ}$. Similar findings were mentioned by Vagadia et al. (2017), they noticed a decrease in TSS from $84.82^{\circ}$ to $83.60^{\circ}$ during 6 months of storage. The gradual increase in the brix and the brix to acid ratio of the jamun leather during the storage is due to the decrease of the moisture level and breakdown of polysaccharides into soluble compounds as mentioned by Basha et al. (2018).

Reducing sugars: Reducing sugars were also calibrated during the storage study. An increasing trend is observed during the storage at from day 0 to day 120 . The maximum rise i.e., $14 \%$ was observed in $\mathrm{V}_{2} \mathrm{~T}_{1}(12.48 \pm 0.41$ at day 0 to $14.49 \pm 0.44$ at day 120 ). Whereas $12 \%$ increase was observed in $\mathrm{V}_{1} \mathrm{~T}_{2}$ i.e., $12.90 \pm 0.45$ to $14.74 \pm 0.44$. Moreover, a gradual rise in reducing sugars was observed from $12.75 \pm 0.47(0$ day), $13.19 \pm 0.46 \quad\left(30^{\text {th }}\right.$ day $), 13.63 \pm 0.50 \quad\left(60^{\text {th }}\right.$ day $)$, $14.28 \pm 0.46\left(90^{\text {th }}\right.$ day $), 14.55 \pm 0.45\left(120^{\text {th }}\right.$ day $)$ as mentioned in Table 3. The results of reducing sugars are similar to the readings of Das et al. (2019) prepared a pomegranate leather using different packing material and stored it in the refrigerator as well as in the ambient room temperature for 60 days. During the study, they observed a gradual increase in the level of reducing sugars in the refrigerator kept sample and the sample stored at ambient temperature. They noticed that the reducing sugars at cold temperatures were 8.12 to $10.05 \%$ which increased to 12.35 to 13.69 . whilst the at ambient temperature reducing sugars ranged between 10.05 to 10.28 which raised to a range of 13.67 to 14.15 . Earlier, Kaleem et al. (2017), prepared strawberry leather using different concentrations of sucrose and honey and examined the different physicochemical and sensory properties of leather. During the study, they determined that reducing sugars decreased during the storage study. They noticed that the reducing sugars in the leather were 19.08 which was reduced to 19.44 during the study of 90 days. Referring to the literature of Sharma et al. (2013), who elaborated the reason 
for the rise in the reducing sugars levels as more conversion of non-reducing sugars to reducing sugars.

Ascorbic acid: The ascorbic acid content of jamun leather showed the treatments of the study due to varietal difference whilst during the storage, there was no significant effect on ascorbic acid. The data displayed in Table 3 showed that $\mathrm{V}_{1} \mathrm{~T}_{1}$ $(6.94 \pm 0.57 \mathrm{mg} / 100 \mathrm{~g})$ has the maximum amount of ascorbic acid followed by $\mathrm{V}_{1} \mathrm{~T}_{2}(6.81 \pm 0.58 \mathrm{mg} / 100 \mathrm{~g})$. The reduction in Vitamin C was observed as from $6.82 \pm 0.60 \mathrm{mg} / 100 \mathrm{~g}$ to $6.33 \pm 0.54 \mathrm{mg} / 100 \mathrm{~g}$ during 120 days. Ascorbic acid is a natural antioxidant entity which may reduce due to the interaction with the surrounding environment such as light and air. The same reduction trend was observed by Vagadia et al. (2017), during the storage of different papaya and banana leather treatments which was 16.14 to $9.14 \mathrm{mg} / 100 \mathrm{~g}$ (treatment having a ratio of papaya and banana as $20 \%$ and $80 \%$ respectively) during storage of 6 weeks, similarly, another treatment having $60 \%$ papaya and $40 \%$ banana exhibited a decrease from 35.24 to $24.23 \mathrm{mg} / 100 \mathrm{~g}$. In another study presented by Tontul and Topuz, (2017), the initial value of ascorbic acid was $23.26 \pm 10.74 \mathrm{mg} / 100 \mathrm{~g}$ which was reduced to $17.57 \pm 13.77 \mathrm{mg} / 100 \mathrm{~g}$ at the end of the study. Saranya et al. (2017) mentioned that the decrease in the level of ascorbic acid might be due to the oxidation process of ascorbic acid and the formation of dehydroascorbic acid in an acidic environment.

Fe determination: In the current study, the treatments showed a significant effect on the iron level of the leather whilst the storage has a non-significant effect on the iron level. A decline was observed from $7.25 \pm 1.26$ to $7.12 \pm 1.02 \mathrm{mg} / 10 \mathrm{~g}$ in $\mathrm{V}_{1} \mathrm{~T}_{1}$, in $\mathrm{V}_{1} \mathrm{~T}_{2}$ iron level was reduced from $10.75 \pm 1.30$ to $10.65 \pm 1.11 \mathrm{mg} / 10 \mathrm{~g}$ from the initial day to the termination day of study. Similarly, in $\mathrm{V}_{2} \mathrm{~T}_{1}$ iron value was dropped from $7.22 \pm 1.28$ to $7.10 \pm 1.09 \mathrm{mg} / 10 \mathrm{~g}$ and in the last treatment $\mathrm{V}_{2} \mathrm{~T}_{2}$ $10.72 \pm 1.27$ to $10.62 \pm 1.05 \mathrm{mg} / 10 \mathrm{~g}$ trend was noticed at 0 day and day $120^{\text {th }}$ day (Table 4$)$. A research was conducted by Zahra et al. (2020), in which the researchers fortified fruit bar with iron fortificants. They observed a decreasing trend in the iron level during the study of 60 days, such as in a treatment iron level was reduced from $11.56 \pm 0.17$ to $11.48 \pm 0.34 \mathrm{mg}$. Similarly, in another treatment iron was decreased from $10.78 \pm 0.01$ to $10.65 \pm 0.17 \mathrm{mg}$ during the storage.

\section{Antioxidant activity of iron-fortified jamun leather}

Total phenolic contents of iron-fortified jamun leather: The total phenolic contents (TPC) of the iron-fortified jamun leather decline during the storage. Both the treatments and the storage had a significant effect on the phenolic contents of the leather. The mean Table 4 predicted that the total phenolic contents of $\mathrm{V}_{1} \mathrm{~T}_{1}, \mathrm{~V}_{1} \mathrm{~T}_{2}, \mathrm{~V}_{2} \mathrm{~T}_{1}$ and $\mathrm{V}_{2} \mathrm{~T}_{2}$ declined from $1377.89 \pm 1.96$ to $1368.99 \pm 1.78, \quad 1375.21 \pm 1.97$ to $1369.43 \pm 1.76, \quad 1299.34 \pm 1.81$ to $1291.63 \pm 1.67$ and $1293.36 \pm 1.78$ to $1283.12 \pm 1.60 \mathrm{mg}$ GAE/100g, respectively. Whilst a higher reduction in TPC of all the treatments was recorded as $1336.45 \pm 1.88$ to $1329.81 \pm 1.76 \mathrm{mg}$ GAE/100g throughout the storage. These results are in harmony with the study conducted Torres et al. (2015) on the apple and quince leather without the addition of any preservative. They observed a significant reduction of TPC during the storage study such as $31 \%$ TPC was reduced in apple leather whereas $49 \%$ reduction in quince leather. Similarly, in another research conducted by Tonul and Topuz, (2017) on the pomegranate leather. During the storage of the leather, the researchers observed a reduction in total phenolic contents from $11.78 \pm 3.41$ to $8.72 \pm 3.65 \mathrm{mg} \mathrm{GAE} / 100 \mathrm{~g}$. Lafarga et al.

Table 4. Effects of storage and treatment on Fe, TPC and DPPH content of jamun leather.

\begin{tabular}{|c|c|c|c|c|c|c|}
\hline \multirow[b]{2}{*}{ Parameter } & \multirow[b]{2}{*}{ Storage Days } & \multicolumn{4}{|c|}{ Treatments } & \multirow[b]{2}{*}{ Means } \\
\hline & & $\mathbf{V}_{1} \mathbf{T}_{1}$ & $\mathbf{V}_{1} \mathbf{T}_{2}$ & $\mathbf{V}_{2} \mathbf{T}_{1}$ & $\mathbf{V}_{2} \mathbf{T}_{2}$ & \\
\hline \multirow[t]{6}{*}{$\mathrm{Fe}(\mathrm{mg} / \mathbf{1 0 g})$} & 0 & $7.25 \pm 1.26^{\mathrm{b}}$ & $10.75 \pm 1.30^{\mathrm{a}}$ & $7.22 \pm 1.28^{b}$ & $10.72 \pm 1.27^{\mathrm{a}}$ & $8.99 \pm 1.28^{\mathrm{a}}$ \\
\hline & 30 & $7.20 \pm 1.24^{\mathrm{b}}$ & $10.73 \pm 1.27^{\mathrm{a}}$ & $7.19 \pm 1.24^{\mathrm{b}}$ & $10.70 \pm 1.23^{\mathrm{a}}$ & $8.96 \pm 1.25^{\mathrm{a}}$ \\
\hline & 60 & $7.18 \pm 1.20^{\mathrm{b}}$ & $10.70 \pm 1.24^{\mathrm{a}}$ & $7.17 \pm 1.22^{\mathrm{b}}$ & $10.67 \pm 1.21^{\mathrm{a}}$ & $8.93 \pm 1.22^{\mathrm{a}}$ \\
\hline & 90 & $7.15 \pm 1.18^{\mathrm{b}}$ & $10.67 \pm 1.20^{\mathrm{a}}$ & $7.13 \pm 1.19^{b}$ & $10.64 \pm 1.19^{\mathrm{a}}$ & $8.90 \pm 1.19^{\mathrm{a}}$ \\
\hline & 120 & $7.12 \pm 1.12^{\mathrm{b}}$ & $10.65 \pm 1.11^{\mathrm{a}}$ & $7.10 \pm 1.09^{b}$ & $10.62 \pm 1.05^{\mathrm{a}}$ & $8.87 \pm 1.07^{\mathrm{a}}$ \\
\hline & Means & $7.18 \pm 1.18^{b}$ & $10.70 \pm 1.22^{\mathrm{a}}$ & $7.16 \pm 1.20^{\mathrm{b}}$ & $10.67 \pm 1.19^{a}$ & \\
\hline TPC (mg & $\mathbf{0}$ & $1375.21 \pm 1.97^{\mathrm{ab}}$ & $1377.89 \pm 1.96^{\mathrm{a}}$ & $1299.34 \pm 1.81^{\mathrm{f}}$ & $1293.36 \pm 1.78^{\mathrm{hi}}$ & $1336.45 \pm 1.88^{\mathrm{a}}$ \\
\hline \multirow[t]{5}{*}{ GAE/100g } & 30 & $1374.26 \pm 1.96^{b c}$ & $1373.17 \pm 1.92^{b c}$ & $1297.23 \pm 1.78^{\mathrm{fg}}$ & $1290.76 \pm 1.75^{\mathrm{ij}}$ & $1333.86 \pm 1.85^{\mathrm{b}}$ \\
\hline & 60 & $1372.11 \pm 1.88^{\mathrm{cd}}$ & $1372.12 \pm 1.89^{\mathrm{cd}}$ & $1294.67 \pm 1.75^{\mathrm{gh}}$ & $1288.02 \pm 1.69^{j}$ & $1331.74 \pm 1.80^{\mathrm{c}}$ \\
\hline & 90 & $1369.67 \pm 1.80^{\mathrm{de}}$ & $1371.76 \pm 1.85^{\mathrm{cde}}$ & $1292.76 \pm 1.72$ & $1285.03 \pm 1.66^{\mathrm{k}}$ & $1329.81 \pm 1.76^{\mathrm{d}}$ \\
\hline & 120 & $1369.43 \pm 1.76^{\mathrm{de}}$ & $1368.99 \pm 1.78^{\mathrm{e}}$ & $1291.63 \pm 1.67 \mathrm{ij}$ & $1283.12 \pm 1.60^{\mathrm{kd}}$ & $1328.29 \pm 1.70^{\mathrm{e}}$ \\
\hline & Means & $1372.14 \pm 1.87^{\mathrm{a}}$ & $1372.80 \pm 1.88^{a}$ & $1294.95 \pm 1.75^{\mathrm{b}}$ & $1288.09 \pm 1.70^{c}$ & \\
\hline \multirow[t]{6}{*}{ DPPH (\%) } & $\mathbf{0}$ & $86.78 \pm 0.57^{\mathrm{a}}$ & $85.36 \pm 0.62^{\mathrm{cd}}$ & $83.45 \pm 0.52^{\mathrm{ghi}}$ & $82.76 \pm 0.53^{\mathrm{i}-1}$ & $84.59 \pm 0.56^{\mathrm{a}}$ \\
\hline & 30 & $86.47 \pm 0.55^{\mathrm{ab}}$ & $84.94 \pm 0.57^{\text {cde }}$ & $83.17 \pm 0.48^{\text {hij }}$ & $82.38 \pm 0.49^{\mathrm{j}-\mathrm{m}}$ & $84.25 \pm 0.52^{\mathrm{a}}$ \\
\hline & 60 & $85.75 \pm 0.54^{\mathrm{bc}}$ & $84.43 \pm 0.57^{\text {ef }}$ & $82.82 \pm 0.48^{\mathrm{ijk}}$ & $81.96 \pm 0.48^{1 \mathrm{~m}}$ & $83.74 \pm 0.52^{b}$ \\
\hline & 90 & $85.06 \pm 0.52^{\mathrm{cde}}$ & $84.21 \pm 0.55^{\mathrm{efg}}$ & $82.53 \pm 0.47^{\mathrm{jkl}}$ & $81.55 \pm 0.47^{\mathrm{mn}}$ & $83.34 \pm 0.51^{b}$ \\
\hline & 120 & $84.52 \pm 0.48^{\mathrm{def}}$ & $83.89 \pm 0.50^{\mathrm{fgh}}$ & $82.10 \pm 0.45^{\mathrm{klm}}$ & $80.97 \pm 0.44^{\mathrm{n}}$ & $82.87 \pm 0.47^{c}$ \\
\hline & Means & $85.72 \pm 0.53^{\mathrm{a}}$ & $84.57 \pm 0.56^{b}$ & $82.81 \pm 0.48^{c}$ & $81.92 \pm 0.48^{\mathrm{d}}$ & \\
\hline
\end{tabular}




\section{Naz, Khan, Shabbir \& Faisal}

(2017) stated that the loss of total phenolic contents and their scavenging activity might be due to the deformity of the cells which become more prone to non-enzymatic oxidation during the storage time of the product. Addai et al. (2016) quoted that the most common reason is thermal deterioration. During the dehydration process, the polyphenols are more likely to have a deformity in structure as compared to other compounds.

DPPH assay of iron-fortified jamun leather: Depending on the varieties the iron-fortified jamun leather showed different levels of TPC and different antioxidant scavenging activity i.e., DPPH activity. In the present study, there was a significant effect of storage and treatment on the DPPH activity. The mean Table 4 displayed a decrease in DPPH along with the storage interval. The maximum decrease in $\mathrm{DPPH}$ was observed in $\mathrm{V}_{1} \mathrm{~T}_{1}$ i.e., $86.78 \pm 0.57 \%$ to $84.52 \pm 0.48 \%$ followed by $\mathrm{V}_{2} \mathrm{~T}_{2}$ which was $82.76 \pm 0.53 \%$ to $80.97 \pm 0.44$. The overall reduction during along the storage days zero, $30^{\text {th }}, 60^{\text {th }}, 90^{\text {th }}$ and $120^{\text {th }}$ was $84.59 \pm 0.56$, $84.25 \pm 0.52,83.74 \pm 0.52,83.34 \pm 0.51$ and $82.87 \pm 0.47$. Das $e t$ al., (2019), prepared a pomegranate leather using different packing material and stored it in the refrigerator as well as in the ambient room temperature for 60 days. They observed a decline in the DPPH in both the environmental conditions. Such as the DPPH reduced from $78.92 \%$ to $66.83 \%$ at a cold environment whilst, at the ambient temperature the DPPH declined to $29.93 \%$ from $78.52 \%$. The decreased scavenging activity of jamun leather during the storage might be due to the deformity of cells which increased non enzymatic activity (Lafarga et al.,2017).

Sensory evaluation of iron-fortified jamun leather: The iron-fortified jamun leather was presented to a panel of 20 judges and evaluation was carried out by using a 9-point hedonic scale. The mean sensory scores of iron-fortified jamun leather treatments are mentioned in Table 5. Colour is one of the most important parameters for the acceptance and success of any food product by the consumers. The storage and treatment have a non-significant effect on the color. The sensory score of color is shown in Table 5, which predicted that maximum color was observed in $\mathrm{V}_{1} \mathrm{~T}_{2}$ which is $7.48 \pm 0.25$ followed by $7.44 \pm 0.27$ in $\mathrm{V}_{1} \mathrm{~T}_{1}$. The score gradually reduced from $7.53 \pm 0.28$ to $7.33 \pm 0.23$ at the end of the study. The flavor is affected by treatments whilst the storage does not affect the flavor of the leather. The results of flavor in Table 5 showed that the maximum flavor was developed by $\mathrm{V}_{1} \mathrm{~T}_{2}$ i.e., 8.92 \pm 0.27 whilst followed by $\mathrm{V}_{1} \mathrm{~T}_{1} 7.7 \pm 0.29$. Whilst the scores for $\mathrm{V}_{2} \mathrm{~T}_{1}$ and $\mathrm{V}_{2} \mathrm{~T}_{2}$ were $6.08 \pm 0.25$ and $6.33 \pm 0.25$ respectively. The flavor attribute reduced from $7.54 \pm 0.28$ to $6.85 \pm 0.25$ during the 120 days. Similarly, the taste of leather the treatments had a significant effect on the taste whilst during the storage, a very non-significant effect was observed.

Table 5. Effects of storage and treatment on sensory evaluation of jamun leather

\begin{tabular}{|c|c|c|c|c|c|c|}
\hline \multirow[b]{2}{*}{ Parameter } & \multirow[b]{2}{*}{ Storage days } & \multicolumn{4}{|c|}{ Treatments } & \multirow[b]{2}{*}{ Means } \\
\hline & & $\mathbf{V}_{1} \mathbf{T}_{1}$ & $\mathbf{V}_{1} \mathbf{T}_{2}$ & $\mathbf{V}_{2} \mathbf{T}_{1}$ & $\mathbf{V}_{2} \mathbf{T}_{2}$ & \\
\hline \multirow[t]{6}{*}{ Color } & 0 & $7.55 \pm 0.28^{\mathrm{a}}$ & $7.58 \pm 0.28^{\mathrm{a}}$ & $7.48 \pm 0.29^{\mathrm{a}}$ & $7.51 \pm 0.27^{\mathrm{a}}$ & $7.53 \pm 0.28^{\mathrm{a}}$ \\
\hline & 30 & $7.49 \pm 0.27^{\mathrm{a}}$ & $7.50 \pm 0.25^{\mathrm{a}}$ & $7.42 \pm 0.26^{\mathrm{a}}$ & $7.46 \pm 0.24^{\mathrm{a}}$ & $7.47 \pm 0.26^{\mathrm{a}}$ \\
\hline & 60 & $7.42 \pm 0.27^{\mathrm{a}}$ & $7.48 \pm 0.28^{\mathrm{a}}$ & $7.37 \pm 0.26^{\mathrm{a}}$ & $7.40 \pm 0.24^{\mathrm{a}}$ & $7.42 \pm 0.26^{\mathrm{a}}$ \\
\hline & 90 & $7.36 \pm 0.26^{\mathrm{a}}$ & $7.42 \pm 0.25^{\mathrm{a}}$ & $7.30 \pm 0.25^{\mathrm{a}}$ & $7.34 \pm 0.24^{\mathrm{a}}$ & $7.36 \pm 0.25^{\mathrm{a}}$ \\
\hline & 120 & $7.34 \pm 0.25^{\mathrm{a}}$ & $7.39 \pm 0.23^{\mathrm{a}}$ & $7.26 \pm 0.23^{\mathrm{a}}$ & $7.29 \pm 0.22^{\mathrm{a}}$ & $7.33 \pm 0.23^{\mathrm{a}}$ \\
\hline & Means & $7.44 \pm 0.27^{\mathrm{a}}$ & $7.48 \pm 0.25^{\mathrm{a}}$ & $7.37 \pm 0.26^{\mathrm{a}}$ & $7.40 \pm 0.24^{\mathrm{a}}$ & \\
\hline \multirow[t]{6}{*}{ Flavor } & $\mathbf{0}$ & $8.92 \pm 0.32^{\mathrm{a}}$ & $7.94 \pm 0.29^{b}$ & $6.55 \pm 0.26^{\mathrm{de}}$ & $6.73 \pm 0.26^{\mathrm{d}}$ & $7.54 \pm 0.28^{a}$ \\
\hline & 30 & $8.79 \pm 0.31^{\mathrm{a}}$ & $7.92 \pm 0.27^{\mathrm{b}}$ & $6.23 \pm 0.26^{\mathrm{ef}}$ & $6.56 \pm 0.25^{\mathrm{de}}$ & $7.37 \pm 0.27^{\mathrm{ab}}$ \\
\hline & 60 & $8.74 \pm 0.28^{\mathrm{a}}$ & $7.64 \pm 0.27^{\mathrm{bc}}$ & $6.12 \pm 0.25^{\mathrm{ef}}$ & $6.28 \pm 0.25^{\mathrm{ef}}$ & $7.17 \pm 0.26^{\mathrm{bc}}$ \\
\hline & 90 & $8.58 \pm 0.28^{\mathrm{a}}$ & $7.57 \pm 0.28^{\mathrm{bc}}$ & $6.07 \pm 0.25^{f}$ & $6.05 \pm 0.24^{\mathrm{f}}$ & $7.06 \pm 0.26^{c}$ \\
\hline & 120 & $8.48 \pm 0.27^{\mathrm{a}}$ & $7.36 \pm 0.26^{\mathrm{c}}$ & $6.45 \pm 0.27^{f}$ & $6.06 \pm 0.23^{\mathrm{g}}$ & $6.85 \pm 0.25^{\mathrm{d}}$ \\
\hline & Means & $8.68 \pm 0.29^{a}$ & $7.67 \pm 0.27^{b}$ & $6.08 \pm 0.25^{\mathrm{d}}$ & $6.33 \pm 0.25^{c}$ & \\
\hline \multirow[t]{6}{*}{ Taste } & 0 & $8.93 \pm 0.33^{\mathrm{a}}$ & $7.92 \pm 0.35^{c}$ & $6.54 \pm 0.36^{\text {efg }}$ & $6.76 \pm 0.35^{\mathrm{e}}$ & $7.51 \pm 0.35^{\mathrm{a}}$ \\
\hline & 30 & $8.80 \pm 0.31^{\mathrm{ab}}$ & $7.90 \pm 0.33^{c}$ & $6.21 \pm 0.34^{\mathrm{fgh}}$ & $6.58 \pm 0.32^{\mathrm{ef}}$ & $7.37 \pm 0.33^{\mathrm{ab}}$ \\
\hline & 60 & $8.67 \pm 0.32^{\mathrm{ab}}$ & $7.84 \pm 0.33^{c}$ & $6.10 \pm 0.31^{\mathrm{gh}}$ & $6.29 \pm 0.33^{\mathrm{fgh}}$ & $7.23 \pm 0.32^{b c}$ \\
\hline & 90 & $8.55 \pm 0.32^{\mathrm{ab}}$ & $7.77 \pm 0.31^{\mathrm{cd}}$ & $6.08 \pm 0.32^{\mathrm{h}}$ & $6.09 \pm 0.31^{\mathrm{h}}$ & $7.12 \pm 0.32^{c}$ \\
\hline & 120 & $8.46 \pm 0.31^{b}$ & $7.38 \pm 0.29^{d}$ & $5.49 \pm 0.33^{\mathrm{i}}$ & $6.08 \pm 0.32^{h}$ & $6.85 \pm 0.31^{\mathrm{d}}$ \\
\hline & Means & $8.86 \pm 0.32^{\mathrm{a}}$ & $7.76 \pm 0.32^{b}$ & $6.36 \pm 0.33^{c}$ & $6.08 \pm 0.33^{\mathrm{d}}$ & \\
\hline Overall & 0 & $8.92 \pm 0.31^{\mathrm{a}}$ & $7.94 \pm 0.29^{b}$ & $6.55 \pm 0.26^{\mathrm{de}}$ & $6.73 \pm 0.28^{\mathrm{d}}$ & $7.53 \pm 0.29^{a}$ \\
\hline \multirow[t]{5}{*}{ acceptability } & 30 & $8.79 \pm 0.29^{a}$ & $7.92 \pm 0.28^{\mathrm{b}}$ & $6.23 \pm 0.24^{\mathrm{ef}}$ & $6.56 \pm 0.26^{\mathrm{de}}$ & $7.37 \pm 0.27^{\mathrm{ab}}$ \\
\hline & 60 & $8.64 \pm 0.29^{a}$ & $7.64 \pm 0.27^{b c}$ & $6.12 \pm 0.24^{\mathrm{ef}}$ & $6.28 \pm 0.26^{\mathrm{ef}}$ & $7.17 \pm 0.27^{b c}$ \\
\hline & 90 & $8.58 \pm 0.28^{a}$ & $7.57 \pm 0.27^{b c}$ & $6.07 \pm 0.25^{f}$ & $6.06 \pm 0.27^{f}$ & $7.07 \pm 0.27^{\mathrm{c}}$ \\
\hline & 120 & $8.48 \pm 0.27^{\mathrm{a}}$ & $7.36 \pm 0.21^{\mathrm{c}}$ & $5.45 \pm 0.23^{\mathrm{g}}$ & $6.05 \pm 0.24^{\mathrm{f}}$ & $6.84 \pm 0.25^{\mathrm{d}}$ \\
\hline & Means & $8.68 \pm 0.29^{a}$ & $7.68 \pm 0.27^{b}$ & $6.33 \pm 0.24^{c}$ & $6.08 \pm 0.26^{\mathrm{d}}$ & \\
\hline
\end{tabular}


The maximum taste score was exhibited by $\mathrm{V}_{1} \mathrm{~T}_{1}$ which is $8.86 \pm 0.32$ following the $\mathrm{V}_{1} \mathrm{~T}_{2}$ i.e., $7.76 \pm 0.32$ (Table 5). The difference in taste and flavor among the treatments may be due to different varieties.

The overall acceptability of jamun leather was maximum in $\mathrm{V}_{1} \mathrm{~T}_{1}(8.68 \pm 0.29)$ and $\mathrm{V}_{1} \mathrm{~T}_{2} \quad(7.68 \pm 0.27)$ than $\mathrm{V}_{2} \mathrm{~T}_{1}$ $(6.33 \pm 0.24)$ and $V_{2} T_{2}(6.06 \pm 0.26)$. The overall acceptance was reduced from $7.60 \pm 0.29$ to $7.41 \pm 0.25$ during 120 days of study (Table 5). The present study's findings are following Saranya et al. (2017), who worked on the papaya fruit rollups. They suggested the sensory attributes were 4.27 to 3.87 for color, 4.47 to 3.67 for flavor, in case of taste and overall acceptability sensory score was 4.20 to 3.80 and 4.47 to 3.92 respectively. Likewise, Zahra et al. (2020) developed an ironfortified fruit bar and conducted the organoleptic analysis of the bar. The sensory analysis was done on a fortnight basis for 60 days. During the research tenure, a decrease in some of the sensory parameters from $0^{\text {th }}$ to $60^{\text {th }}$ day and concluded that the reason behind the decrease in the flavor, taste and overall acceptability score might be the physicochemical changes during the storage. Similarly, Kaleem et al. (2016) mentioned that the decline in the color of the leather might be due to the deterioration of the pigment moreover the researchers warned the Millard reaction as a reason for the change in the color during the storage. The maximum rating of all the sensory attributes was observed in $\mathrm{V}_{1} \mathrm{~T}_{1}$ throughout the storage.

Conclusion: Jamun and its derived products have been proposed to have health promoting properties. The present study was carried out to prepare fortified jamun leather for consumption by targeted population using two jamun varieties having specified RDA values of ferrous sulfate to overcome the iron-deficiency anaemia situation. The experiment results related to the fortified jamun leather prepared using different concentration of iron salt was acceptable throughout the 120 days storage period at ambient temperature. In the present study, the iron level of fortified leather remained the same throughout the storage in a range of 7.16-7.18 and 10.67 to $10.70 \mathrm{mg} / 10 \mathrm{~g}$. The highest ascorbic acid was observed in $\mathrm{V}_{1} \mathrm{~T}_{1}$ as $6.94 \pm 0.57$, similarly, the maximum level of reducing sugars was noticed in $\mathrm{V}_{1} \mathrm{~T}_{1}$ i.e., $13.82 \pm 0.48$. In case of sensory evaluation, the $V_{1} T_{1}$ and $V_{1} T_{2}$ secured the highest scores in overall acceptability as $8.68 \pm 0.297 .68 \pm 0.27$ correspondingly. Moreover, on the basis of chemical and organoleptic analysis, the $\mathrm{V}_{1}$ variety i.e., Desi jamun was considered to be more stable in comparison to the other variety.

Acknowledgment: The authors are grateful to Higher Education Commission (HEC), Pakistan for supporting this study. The corresponding author is thankful to co-authors for their keen interest and guidance.

\section{REFERENCES}

Addai, Z. R., A. Abdullah, S. A., Mutalib and K. H. Musa. 2016. Evaluation of fruit leather made from two cultivars of papaya. Ital. J. Food Sci. 28:73-82.

Ahmad, N., S. N. Shafii, N. H. Hassan, A. Rajab and A. Othman. 2018. Physicochemical and sensorial properties of optimised roselle-pineapple leather. Malaysian J. Anal. Sci. 22:35-44.

Akhtar, J., I. Bano, R. K. Pandey, A. Husainb and S. Malik. 2014. Effect of different level of pectin and starch on quality and storage stability of apple-date fruit bar. J. Food Prod. Develop. Pack. 1:31-36.

AOAC. 2016. Official Methods of Analysis. The association of official analytical chemists. Inc. 18th Ed. Arlington, USA. 1-48.

Asad, N. and A. Mushtaq.2012. Malnutrition in Pakistani children, its causes, consequences and recommendations. J. Pak. Med. Assoc. 62:311-312.

Balarajan, Y., U. Ramakrishnan, E. Ozaltin, A. H. Shankar and S. V. Subramanian. 2011. Anaemia in low-income and middle-income countries. The Lancet. 378:21232135.

Basha, S. J., N. G. Shivshankar, S. Pande and V. Shaziya. 2018. Studies on development of guava leather as a novel product. Int. J. Chem. Stud. 6:1920-1929.

Bukya, A. and L. P. Madane. 2018. Preaparation and standardization of jamun jam (Syzygium cumini) it's chemical and storage studies. World J. Pharm. Pharm. Sci. 7:876-885.

Chavan, U. D. and J. B. Shaik. 2015. Standardization and preparation of guava leather. Int. J. Adv. Res. Bio. Sci. 2:102-113.

Das, K., M. Kumar and A. Das. 2019. Standardization of Packaging Material and Storage Condition for Pomegranate Leather. Int. J. Curr. Microbiol. App. Sci. 8:2748-2760.

Dwyer, J. T., C. Woteki, R. Bailey, P. Britten, A. Carriquiry, P. C. Gaine and E. M. 2014. Fortification: new findings and implications. Nutr. Rev. 72:127-141.

Kaleem, I. M. Qazi, M. A. Khan, I. Hussain, M. Ayub and A.U. Rehman 2017. Effect of Different Concentrations of Sucrose and Honey on the Physiochemical and Sensory Properties of Strawberry Leather. Bio. Sci.Pak.J.Sci.Ind. Res.60: 1-10.

Khayum, A., H. C. Krishna, G. K. Sadananda, A. M. Gowda, T. H. Shankarappa and S. Taj. 2018. Development of value-added product of jamun syrup blended with avocado and Nannari. J. Pharm. Phytochem. 7:776-780.

Ghosh, P., R. C. Pradhan, S. Mishra, A. S. Patel, A. Kar. 2017. Physicochemical and nutritional characterization of jamun (Syzygium cuminii). Current Res. Nutr. Food Sci. J.5:25-35.

Nawaz, M. S., A. S. Sheikh, A. M. Nizamani, M. I. Bhanger and I. Afridi. 2010. Determination of mineral elements in 


\section{Naz, Khan, Shabbir \& Faisal}

Jamun fruit () products. Pak. J. Food Sci. 20:1-7. Eugenia jambolana

Offia-Olua, B. I and O. A. Ekwunife. 2015. Production and evaluation of the physico-chemical and sensory qualities of mixed fruit leather and cakes produced from apple (Musa pumila), banana (Musa sapientum), pineapple (Ananas comosus). Nigerian Food J. 33: 22-28.

Phuong, H. M. K., N. D. H. Hoa and N. V. H. Ha. 2016. Effects of added pectin amounts and drying temperatures on antioxidant properties of mulberry fruit leather. J. Biotechnol. 14:487-495.

Prabhakaran, S., K. M. Gothandam and K. Sivashanmugam. 2011. Phytochemical and antimicrobial properties of Syzygium cumini an ethanomedicinal plant of Javadhu hills. Res. Pharm. 1: 22-32.

Torres, C. A., L. A. Romero and R. I. Diaz. 2015. Quality and sensory attributes of apple and quince leathers made without preservatives and with enhanced antioxidant activity. LWT-Food Sci. Pharma. 62:996-1003.

Saeed, A., S. Kauser and M. Iqbal. 2018. Nutrient, mineral, antioxidant, and anthocyanin profiles of different cultivars of Syzygium cumini (jamun) at different stages of fruit maturation. Pak. J. Bot. 50:1791-1804.

Saranya V, K. U. Devi, J. Suneetha and K. B. Suneetha. Development and shelf-life study of papaya fruit rollups. J. Pharm. Phytochem.6:1420-1424.

Sartaj, A.T. M., K.S. Abbasi, A.Ali and A. Hussain. 2013. Some compositional and biochemical attributes of jaman fruit (Syzygium cumini L.) from Potowar region of Pakistan. Res. Pharm. 3:1-9.
Shakoor, A., M. Ayub, S. Wahab, M. Khan, A. Khan and Z. Rahman. 2015. Effect of different levels of sucroseglucose mixture on overall quality of guava bar. J. Food Process. Technol. 6: 1-7.

Sharma, P., M. Ramchiary, D. Samyor and A. B. Das. 2016. Study on the phytochemical properties of pineapple fruit leather processed by extrusion cooking. LWT- Food Sci. Technol. 72:534-543.

Suradkar, N. G., V. S. Pawar and D. M. Shere. 2017. Physicochemical, proximate and bioactive composition of jamun (Syzygium cuminii L.) fruit. Int. J. Chem. Stud. 5:470-472.

Tontul, I. and A. Topuz. 2017. Effects of different drying methods on the physicochemical properties of pomegranate leather (pestil). LWT- Food Sci. Technol. 80: 294-303.

Vagadia, P., A. Senapati, R. Tank, J. Mayani and B. Koyani. 2016. Evaluation of Physico-chemical and organoleptic quality of Papaya and Banana based mixed fruit bar during storage. Int. J. Agri. Environ. Biotechnol. 9:541544.

Viswanath, M., K.Venkataramudu, B. Srinivasulu, K. Gopal and K. S. Lakshmi. 2018. Processing for value addition of minor fruits. J. Pharm. Phytochem. 7: 1555-1559.

Zahra, S. M., S. Hussain, S. Mahmood, T. Kausar, G. M. U. Din, T. Tufail, and M. Z. Shahid. 2020. Shelf stable iron fortified fruit bar's development, proximate estimation and organoleptic characterization. Int. J. Biosci.16:111135. 